\title{
技術の話題
}

\section{大河ドラマ「山河燃ゆ」の新しい映像合成 ビデオマットの開発}

\author{
正会員 門 條 由 男 ${ }^{\dagger}$, \\ 田村 久 男 ${ }^{\dagger}$ \\ 新 倉 輝 雄 $^{\dagger}$
}

NHK では, ビデオマットの開発により新しい映像合成手法で，昨年の大河ドラマ「山河燃ゆ」か ら番組制作を行っているこの合成手法は, 番組演出上および制作経費節減に多大な効果をもたら したその特徵と番組制作の方法について述べる

\section{1. まえ がき}

いま，番組制作現場で最も多く使用されている画面 合成の代表的なものとして，クロマキー合成やワイプ 合成があるこれらの合成方法は，より自然な合成， あるいはより変化をもたせた合成が求められており， 現在さらに開発も行われているここで紹介する新し い映像合成手法は，クロマキー合成の手法とワイプ合 成手法の中間ともいうべき合成手法であり，従来のク ロマキー, およびワイプ方式では不可能であった $2 つ$ のビデオロケ画面の合成を行うものである

このグラフィックコンピュータを応用した新しいキ 一信号発生装置（以下，ビデオマット）を用いた番組 制作における画面の合成方法と特徵について説明す る

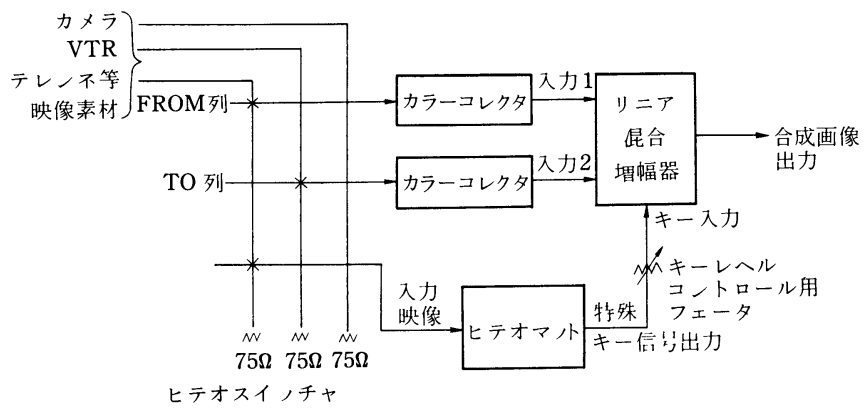

凶 1 ヒテオマットによる画面合成システム

\footnotetext{
$\dagger$ NHK 技術本部

"Video-Matte- - A New Method of Video Synthesis Developed by NHK- - by Yoshıo Monjo, Hisao Tamura and Teruo Nıkura (NHK Engineerıng Headquarters, Tokyo)
}

\section{2. 画面合成の方法}

映像合成に必要なシステムは，図 1 に示すように， カラーコレクタ, リニア混合幅幅器, ビデオマットか ら構成されている 図19ように, カメラ, VTR, テレシネ等の映像素材から, ベースとするべき映像 （前景映像, 写真 1）を, ビデオスイッチャを介して, FROM 列と共にビデオマットに取り込む 次にTO 列に合成する映像 (写真 2) を選択するこの 2 つの映 像と, ビデオマットで発生させた映像の境界条件に合 った特殊キー信号 (写真 3) とを, キーレベルコントロ ール用フェーダにより,さらにマッチさせてリアルな 合成画面（写真 4) を得る

\section{3. ビデオマットによる映像合成の特徵}

（1）クロマキー合成では困難であった，2つのビ デオロケ映像の合成が可能となった

（2）ビデオマットで発生するキー信号 は，ソフト化されているため，このキー信号 を使って画面合成を行うことにより，オリジ ナル映像の持つリアル感は損なわれることな く, 自然な合成ができる

（3）クロマキー合成では，スタジオのセ ットバックにブルー等の色のスクリーンを作 る必要があるそのため, 大規模なセットの 場合には，事実上不可能であったが，これら の影響を受けない

（4）キー信号の作成には，ライトペンを 使用しているため，簡单にキー信号を作るこ とができる

（5） キー信号をグラフィックコンピュー 夕により発生させているため, 画面内の不要

(43) 705 


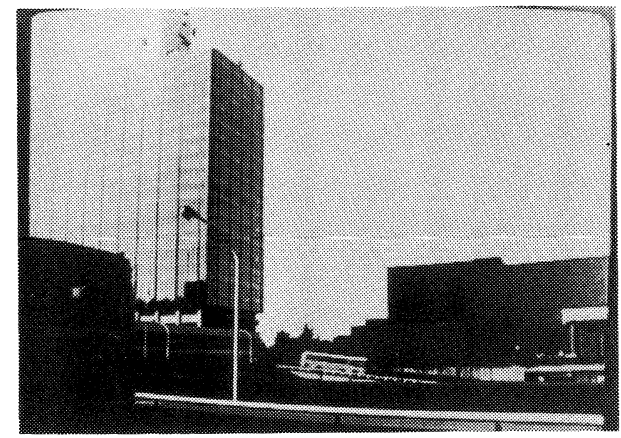

写真 1 ベースとなる前景映像

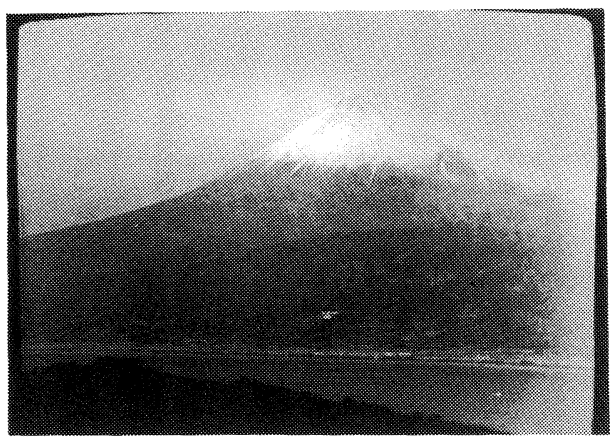

写真 2 合成するバックの映像

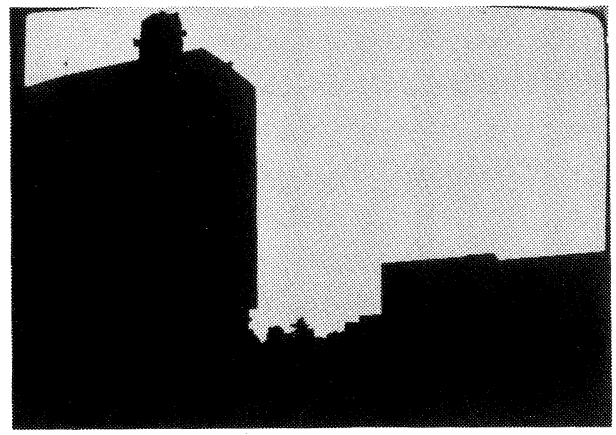

写真 3 ビデオマットで発生させた特殊キー信号

な部分を簡単に削除することができる。

\section{4. 番組制作への使用}

NHK では，ビデオマットによるこの新しい映像合 成手法を, 昨年の大河ドラマ「山河燃ゆ」の番組から 取り入れ運用を開始している。この番組では, 演出上 非常に重要なシーンである, 現存しない, アメリカに おけるマンザナール収容所の映像合成を行った．その 方法は, 事前にアメリカロケで撮ってきたシェラネバ ダ山脈を望む風景と埼玉県川口市の NHK 放送所跡 地に組まれたセットでのロケシーンを 1 つの画面にし たものである．その合成映像を写真 5 に示す，この映 像合成は, オリジナル映像の持つ迫力感, リアル感を

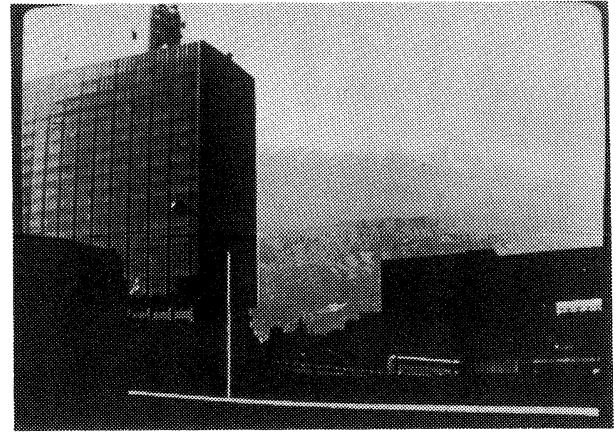

写真 4 完成した合成映像

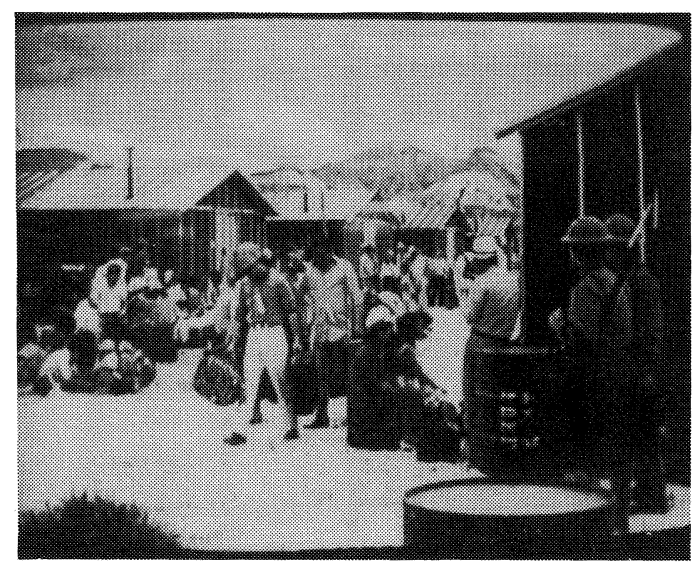

写真 5 大河ドラマ「山河燃ゆ」での合成映像

そのまま生かした形で架空の映像を表現でき，あたか もその現場に行って撮影しているかのような雾囲気を 簡単に作り出すことができた，このことは, 番組演出 上, 特に重要なカットについては, あらかじめ演出上 での想念を描き, 番組制作していくならば, 今までと 一味違った高画質の新しい絵づくりが可能となり, 情 感あふれる演出手法を可能としたものである.

\section{5.むす び}

このビデオマットによる映像合成手法は, フィール ド映像および大型セット前でのビデオ合成が簡単にで きるという特徴を持っている.NHKではこの特徵を 利用して, ロケ番組制作費の節減, 制作期間の短縮, およびスタジオの有効利用を可能とした，今後は，ド ラマ番組に限らず, インフォメーション, 教育番組等 についても, その用途は非常に大きいものと考えられ る.このため, 番組制作の画期的手法として, 各方面 から期待されている。

最後に，ビデオマット開発にあたり多大なる御協力 をいただいた関係各位に，誌面をかりて深謝する。

(昭和 60 年 6 月 3 日受付) 